\title{
Law, Journalistic Profession and Mass Media Ethics
}

\author{
M. Yoserizal Saragih \\ Universitas Islam Negeri Sumatera Utara, Indonesia \\ yosesaragih77@gmail.com
}

\begin{abstract}
In law and mass media studies, morals and ethics are linked to the obligations of journalists, such as; the implementation of journalistic code of ethics in every journalistic activity is subject to legal institutions and regulations to carry out with good etiquette as the provisions in the law, which are a set of principles and rules that have generally been accepted and approved by the public. In this regard, ethical principles for the journalistic profession provide a legal basis for managing news in the media in an orderly manner in the relationship between legal subjects. In developments in media institutions in Indonesia, the aspects of share ownership in the media (leadership), economics and media marketing will greatly determine the ideology that is promoted by the media, where this ideology, if it leads to a political economy approach, will create media actors who are less familiar with communication ethics. Communication ethics here are positioned as mere instruments and become less meaningful in determining program content, program quality and media actors' respect for human rights that are represented by individuals as sources of information. This choice raises communication ethics on media actors who are considered to have experienced a reduction. Media players as a profession have taken a shortcut by referring to the principle of benefit, prioritizing the principle of benefit in its coverage and news, which is also paradoxical with the professional ethics it carries. To make matters worse, the absence of respect for the presumption of innocence in the name of the public's interest in obtaining information will increasingly make the mass media and media actors as dominant persons in reconstructing and manipulating social reality. Up to this point, the choice of the tendency to interpret the political economy approach or the ethical approach, in fact both of them do not have obvious legal implications, all of them are returned to each individual who is involved in activities in mass media institutions.
\end{abstract}

Keywords

deontology; reduction; profession; communication ethics and journalism

\section{Introduction}

Basically, morals and ethics are principles and values which according to the belief of a person or society can be accepted and implemented properly and properly. Thus, these principles and values are related to the right and wrong attitudes that they believe. Ethics itself as part of the philosophy is a system of moral principles including the rules for implementing them. In law and mass media studies, morals and ethics are linked to the obligations of journalists, such as; implementation of journalistic code of ethics in every journalistic activity, subject to legal institutions and regulations to carry out with good etiquette as the provisions in the law which are a set of principles and rules that have generally been accepted and approved by the community.

In this regard, ethical principles for the journalistic profession provide a legal basis for managing news in the media in an orderly manner in the relationship between legal 
subjects. Ethics generally function to protect human interests, so that journalistic journalism can take place and be felt by humans that the news is functioning and pleasing to a sense of serenity and peace.

In this case, the role of upholding the professional ethics of journalism is very dominant. Then to achieve the upholding of ethics and the functioning of the law, the law and the enforcement of ethics must exist or be in existence, which is to function as a control so that a peaceful system of kerta raharja is achieved. Nowadays there is often a clash between the phenomenon of uniformity of news in the mass media as a result of references to media institutions and personnel involved in the consumption of Law, Journalism Profession and Mass Media Ethics ... (Abdul Choliq Dahlan) 397 on the one hand, and the meaning of journalism ethics in media institutions and journalists as a profession, on the other hand, should demand that their journalistic activities are always colored by the journalistic code of ethics that confines them.

In the current state of the modern economy, conditions have changed, the emergence of competition in the business world is unavoidable. With competition, business people must be more observant in reading opportunities and threats. A business can be successful if it successfully pays attention, retains and grows customers. Basically, the purpose of establishing a company is to get maximum profit. Therefore we need a smooth marketing (Marlizar et al, 2020). The fastest way to get attention from consumers and in a wide variety of ways in which organizations have been found to connect with their consumers is through social media (Icha in Gunawan and Sulaeman, 2020). Service marketing association refers to a set of marketing means used to achieve the marketing goals within the target market, comprising product, price, promotion, place, people, physical evidence and process of which all variables involved are controllable by a particular organization or board for the sake of competitive advantage (Haksever et al in Kusumadewi, 2019).

The economic interests of institutional marketing and the idealism principles of the journalistic profession in the era of media convergence have recently become important stakes that will determine the sustainability of the media in the future. However, what is the right choice and option from the two, that is what will be discussed in this paper.

\section{Review of Literature}

The realm of journalism does have its uniqueness as a profession compared to other forms of cultural production. According to Bourdieu in Haryatmoko (2007) there are 3 (three) things that mark the uniqueness of journalism which is directly related to communication ethics. First, journalism is highly dependent on external pressures, namely the law of demand, so it is largely determined by market sanctions and audience plebiscites. Second, the polar distinction with commercial orientation or not feels very strong so that the benefits are more enjoyed by the commercial orientation, even the quality is often measured by its financial strength; the tendency then to regard the ability to form public opinion to be equated with financial strength. Third, the professional atmosphere is very much colored by the implementation of immanent justice (a kind of karmic law).

This principle wants to ensure that those who violate certain prohibitions will be plagued by themselves, while those who conform to the rules of the game are highly praised and respected. The three distinctive colors of journalism are strongly related to communication ethics because if it puts too much emphasis on the market, a plebiscite will bring sanctions. Interactions between journalists and colleagues who take immanent justice seriously will further strengthen the deontology of the profession. According to Sunarto 
(2009), to explain how such social interaction takes place, the context of mass communication is used based on critical political economy theory as a framework of thought that pays attention to the relationship between the ideological content of the media, the dynamics of media organization, and the political economy structure. According to Sunarto (2009) theory emphasizes the structure of media ownership, media control, and the workings of media market forces. In view of this theory, media institutions are seen as part of an economic system that is closely related to the political system. In the political economy of the media, the variants of instrumentalism (as well as professional ethics) are imperceptible.

This is due to the influence of the perspective of social action which emphasizes aspects of individual determinism which sees human behavior not as influenced by society, but society is a product of human activity through individual actions and law, groups. In the context of the television industry, the interaction between agents is seen to play an important role in determining the content of television programs to meet the personal goals of these agents. In practical terms, this personal goal is represented by the power of the share owner to protect his personal interests.

Furthermore, according to Sunarto (2009), in an effort to protect personal interests, media owners collaborate with other agents in the political, social and cultural sphere to jointly protect their personal (communal) interests. It seems that personal (communal) interests are separated from the influence of existing economic, political, social, cultural and ethical structures. Such individual determinism is a major weakness of the instrumentalist approach. Referring to Sunarto's opinion above, the writer assesses the urgency of teaching communication ethics, which is not only for journalists, but also for the shareholders of mass media institutions, so that a synergy is built to achieve just needs and interests with the rights of the people to obtain quality and honest information.

According to Frans Magnis Suseno (2001) ethics in this context is oriented towards society as a whole. An action is called ethical when it involves and is in accordance with the moral views of society. Thus, the dimensions of the journalistic profession of the press can be determined as a dimension in which humans are aware of themselves as members of society as a whole that determines the framework of their lives and is re-determined by their actions. In countries with highly developed democracies, issues of morality and ethics are very important determinants of a person's career in pursuing his profession.

\section{Discussion}

There are many ethical issues in question, not only in our country. However, this discussion about ethics and its problems has been made for a long time and always endeavored so that this ethic can really develop and be attached to every profession. Even in ancient times, Hippocrates has stated that medical science should only be taught to people who are truly sacred persons.

Therefore, in the history of Hippocrates' life journey, he only wanted to accept and teach a student if the student was really a sacred person. The relationship between knowledge, people and sacred persons is a rule and norm that is expected by the profession, knowledge and ethics, in order to be able to carry out the profession and be called a professional. This is because the code of ethics of a profession is a requirement and a necessity to carry out the profession professionally based on noble human values. There can be a decline in the activities of the journalistic profession in its development activities as a result of violations of professional ethics and code of ethics by some of its practitioners. 
Questions about ethics and professional code of ethics as well as 398 Legal Journal, Vol XXV, No. 1, April 2011 why a profession requires ethics and a code of ethics, will produce answers that depend on the definition of the word profession. This statement gave birth to a question "why has the journalistic profession and professionalism in Indonesia been reduced?". Etymologically, the words profession and professional actually have several meanings. Profession in everyday speech can be defined as a (permanent) job to earn a living, both legal and illegal. Profession is defined as any job to earn money.

In a more technical sense, profession is defined as any particular activity to earn a living which is carried out in a skillful manner related to the way of work and high quality work, with high pay rewards. Expertise is acquired through a process of experience, by studying at certain educational institutions, intensive training or a combination of the three. In terms of this definition, professionalism is often distinguished from professionalism as opposed to amateurism and amateurism in the schematic paradox. It is also often said that permanent work is the opposite of odd jobs. Roscue Pound, a legal philosopher of the Sociological Jurisprudence who is famous for his idea of law as "a tool for social engineering", his views in the sense of a profession are basically in line with Parsons.

According to Parsons, "professionals are not capitalists, workers (laborers), government administrators, bureaucrats, or land owners. The scope of the profession as an institution is not clear and firm. In reality there are marginal groups whose professional status is equivocal. However, this criterion for qualifying an occupation as a profession is quite clear, namely that the profession requires formal technical education, Legal, Journalistic Profession and Mass Media Ethics ... (Abdul Choliq Dahlan) 399, equipped with institutionalized testing of the adequacy of education and competence the people he trained. The testing of prospective professional bearers, first, places great importance on evaluating cognitive rationality applied to certain specific fields because it places great emphasis on the intellectual element.

Within the environment of a profession, a value system is applied which functions as a nomative standard which must become an orientation framework in the development of the profession concerned. Third, to ensure that the competence of an occupational complexity (social work system) will be used in a socially responsible manner, it must have a number of institutional means, in the form of professional organizations, ethics and professional code of ethics with enforcement procedures, as well as how to recruit professional caretakers.

Based on these criteria, in general it can be said that the profession refers to the occupational complex in which intellectual disciplines around it include the humanities, natural sciences and social sciences, organized, as well as cultural systems (values) that are processed by and within the occupational complex. The special characteristic of occupation as an occupational system according to Parsons is that the profession is not oriented towards disinterestedness. The occupational sector in media institutions should have a perspective on activities as stated by Parsons above, where media institutions should have idealism, namely to provide correct information. With such idealism, the media want to play a role as a means of education. Viewers, readers and listeners will increasingly have a critical attitude, independence and depth of thinking. However, reality often has a different direction. 400 Legal Journal, Vol XXV, No. 1, April 2011 opposite. The pace of reality is often colored by the structure of economic meaning which is felt to hinder that idealism.

Commercial dynamism seems to be the dominant force in determining the meaning of messages and beauty (aesthetics). Market logic directs the organization of information systems. Many media leaders who come from the corporate world are willing to justify this market logic. It is as if journalism's competence is only a production factor whose first 
function is to support market interests. This market reality illustrates how the mass media is under the pressure of a tough and fierce competitive economy. Competition law demands that the mass media be able to present the latest information, not being preceded by other media. CNN's slogan "Slow news, no news" is an illustration of the intense competition between the media. Only by maintaining actuality can economic benefits be obtained. This advantage will ensure the sustainability of a media. Actual, quickly and concisely defines a short time logic.

Economic pragmatism forces the media to completely adopt the logic of short time (chasing deadlines). This logic demands that work organization be timely, concise and profitable. The same logic also creates the assumption that good information is if it obtained in person, live coverage, live broadcasts, reporting to the scene and information from the first source. The speed of obtaining news is not sufficient to guarantee the sustainability position of a media. In order not to be left behind by consumers, the media must always be able to emphasize their uniqueness and give an attractive presentation. This demand drags into a tendency to show the spectacular and sensational. Appearances like this usually tend to be superficial, because they want to touch many people and the Law, Journalism Profession and Mass Media Ethics... (Abdul Choliq Dahlan) 401 is not detrimental, it is sought that pleases all parties, then what is displayed is similar to sundries.

In television media, high ratings are a measure of success. As for newspapers and magazines, the applicable criteria is the number of subscribers, which in turn will greatly determine the attractiveness of advertisers. The peculiarities that should shape the image of a media (media identity) ironically drag it into a trap. Even more tragic is what is often not realized is the trap of mimeticism. The media's desire to have a distinctive appearance often leads to uniformity. Media mimetism shows how important / not reporting is often determined by the extent to which other media are encouraged to cover it.

Determining the importance of a news report seems to lie in the extent to which other media wants it. The scope of maneuver that should be opened up to cultivate its uniqueness (media identity), ultimately that identity is not created because it has to adapt (adaptation) to the passions of other media. If they do not report what other media are reporting, there is a kind of fear of being left by viewers or readers, then what is at stake is economic gain. Such is the depth of the influence of economic determinism in the media world in Indonesia, so that the hierarchical value is determined by mass consumption, while journalists' ethics and professionalism are often defeated. Journalist as a profession is essentially a qualified occupation which demands high skill requirements from its bearers and implementers. A journalist is required to have high social sensitivity, by making a positive contribution from his coverage and news.

This of course cannot be obtained 402 Jurnal Hukum, Vol XXV, No. April 1, 2011 was released from the function of the mass media as an institution where journalists function as education, disseminating information and entertaining. Basically, there are 3 (three) main criteria to qualify whether an occupation can be called a profession or not. As for the first, is that the profession is different from ordinary occupations, will be carried out on the basis of high expertise, and therefore can only be entered by those who have undergone very advanced technical education and training. In this connection, every profession always develops institutions to set the standards of expertise needed to streamline professional services and at the same time also assessing the ability of individuals who undergo the profession (to maintain the standard of expertise is maintained). 
Second, is that the profession requires that the skills it uses always develop reasonably and be developed regularly in line with the needs of the community which a profession that masters professional expertise serves. Thus the standard of expertise demanded by the profession will not be static and conservative, but will always be dynamic and progressive, in line with the development of society that the profession has to serve. Third, the profession always develops institutions and institutions to control so that professional skills are utilized responsibly, starting from a sincere and selfless dedication and all of this is thought for the benefit of others.

From the affirmation of the definition of a profession as mentioned above, it can be seen that what is called a profession actually rests firmly on a legal ideology or ideology, the Journalistic Profession and Mass Media Ethics... (Abdul Choliq Dahlan) 403 professionalism, which we can always see the components 2 (two); an engineering component (technology) and an ethical component. These two components are actually elements of the sine qua non in the overall ideology and ideology of professionalism, although in practice (especially in recent times) the technical dimension tends to be emphasized and prioritized more than the ethical one. Whereas according to the concept, without an ethical component, what is called a profession will easily fall into practices of abuse of high skills. Experts work to realize the virtues that are highly valued by society (in exchange for special status and honor), and will operate by exploiting technical skills without any restraint for the personal gratifications of the elite professional.

If the components of professional ethics experience severe erosion, then the so-called profession and professionalism can actually be accused of denying their own vows that have been recorded in history in Western Europe, where the ideas and concepts of professionalism were born and developed. Up to this point, the meaning of professional activity can be said to have undergone a reduction, due to pressure, pressure and other interests that are able to erode the idealism of the professional carrier.

In many cases in Indonesia, professions that have experienced a reduction are generally due to economic pressure, political pressure, social pressure in addition to the mushrooming attitude of individual pragmatism in response to the rapidly developing and rapidly developing socio-economic dynamics. Sociologically, the reduction in the journalistic profession can be categorized as a pathological symptom, in which the developing social environment does not consider that the meaning of profession is something noble and noble and has a social responsibility inherent in the profession it carries. Categorized as a pathological symptom due to the current consumerism, hedonic, pragmatic and instant mentality that has developed in society has been considered as a "truth" and in accordance with the demands of the times, so that a flexible attitude towards social phenomena is considered a necessity.

Professions that have experienced a reduction have thus not prioritized the ethics of virtue as they should be used as a reference in carrying out their journalistic activities. Such erroneous and uncorrected developments will certainly have a profound effect on the development of professionalism and especially in journalistic life in Indonesia. Teaching ethics in Indonesia, on the one hand, still places great emphasis on technical materials on legal materials, and still does not worry about socializing the meaning of professionalism through teaching ethics. Meanwhile, on the other hand, the development of professionalism according to the ethical concept in a consumptive and hedonistic industrial society is no longer supported. As a result, legal management as in media institutions and the personnel involved in it, places great importance on its technical aspects, and does not ignore the ethical aspects of a sanctioned profession (except for purely lip service purposes) and is threatened to fall into an ordinary occupation only. 
The obstruction of the process of respecting ethics in the journalistic profession and media institutions as a result of the desacralization of the meaning of profession and professionalism will in fact further alienate the aspirations of a country to realize a raharja culture of peace. Many of the most important aspects of society's order depend to a large extent on the proper functioning of the professions. Journalistic activities and provision of information by law, journalistic profession and mass media ethics... (Abdul Choliq Dahlan) 405 honesty to the wider community is carried out in a professional context. In the rules and order of modern society, the results of the functioning of the professions are closely intertwined. Professions in the occupational social system (work) occupy a very strategic position. The professions and professionalism many people talk about are not only limited to their understanding, but also include questions of their function in the development of a modern industrial society.

From the observations of researchers who are concerned with social change, it can be concluded that in history there has never been a successful industrialization process without being accompanied by a process of professionalism for certain types of employment (occupation). High skills and competent abilities to master advanced technology which are actually the true characteristics of a person with professional qualifications, inevitably become an absolute requirement for enabling industrial development. This is because special abilities and expertise like that are required for almost every position in the industrial work system, so that no doubt the professionalization process will be spurred during the industrialization process of a society. When the industrialization process at the end of the twentieth century has not only occurred in the environment of Western economic civilization, but has also become an important global phenomenon, not only to be understood but also to be lived.

In this case, intense competition and market demands often lead media actors to ignore deontology. Not only because of the problem of erosion of the spirit of the profession or the lack of discipline, but the problem is even more fundamental, namely the problem of the structure of meaning. Nowadays, the structure of meaning emphasizes the economic aspect. This structure of meaning tends to accept only a utilitarian ethical approach. This kind of ethics, because it emphasizes the principle of benefit too much, can become insensitive to ethical demands in matters of procedure or choice of means. The abuse is possible quite often because it adopts this utilitarian perspective. In journalistic practice, for example; violation of someone's private life (privacy), or the lack of respect for the presumption of innocence is often justified in the name of the public's right to information. So the utilitarian (teleological) perspective focuses on a useful end. As a result, anything or anyone that does not provide benefits will be easily ignored, including the basic rights of other parties.

In journalistic practice, the teleological approach often leads media actors to be less sensitive to social phenomena that should be informed, so in this case it is necessary to critically discuss the use of deontological moral traditions. Deontology morals closely direct the actors of communication. Goodwill manifests itself in the performance of obligations without strings attached. This deontological perspective will pay close attention to the conditions and processes that make it possible to seek good or virtue. The moral value of an action or activity is based on a conditioning principle regardless of the consequences. So, moral values are intrinsic and universal. 


\section{Conclusion}

Teleological approaches are also often used to solve problematic actions that have multiple effects. When a journalist gets information from a news source that it must be kept secret that there has been massive corruption, even though the funds should be budgeted for dealing with an epidemic of infectious diseases. When the information is reported, corruptors will easily find out who provided the information. The safety of the informant and his family is in danger and it is almost impossible to leave the area. Moreover, corruptors are the rulers who have strong support and networks. However, if it is not reported, it will endanger the fate of many people. The proportionalism (teleology) approach will justify the reporting of the corruption case with a note.

From the description and illustration above, it can be concluded that the aspects of share ownership in the media (leadership), economics and media marketing will greatly determine the ideology promoted by the media, where the ideology if it leads to a political economy approach, the media will create less familiar media actors with communication ethics. Communication ethics here are positioned as mere instruments and become less meaningful in determining program content, program quality and media actors' respect for human rights that are represented by individuals as sources of information. This choice raises communication ethics on media actors who are considered to have experienced a reduction.

Media actors as a profession have taken a shortcut by referring to the principle of benefit by prioritizing the principle of benefit in its coverage and reporting, which is also paradoxical with the professional ethics it carries. To make matters worse, the absence of respect for the presumption of innocence in the name of the public's interest in obtaining information will increasingly make the mass media and media actors as dominant persons in reconstructing and manipulating social reality. Up to this point, the choice of the tendency to interpret the political economy approach or the ethical approach, in fact, both do not have obvious legal implications, all of which are returned to each individual who is involved in activities in mass media institutions.

\section{References}

Frans Magnis Suseno. (2001). Etika Dasar; Masalah-Masalah Pokok Filsafat Moral. Kanisius. Yogyakarta.

Gunawan, G. G., Sulaeman, M. (2020). Determining Factors in the Use of Digital Marketing and Its Effect on Marketing Performance in the Creative Industries in Tasikmalaya. Budapest International Research and Critics Institute-Journal (BIRCIJournal), Vol 3, No 3, Page: 2543-2550.

Haryatmoko. (2007). Etika Komunikasi: Manipulasi Media, Kekerasan, dan Pornografi. Kanisius. Yogyakarta.

Koentjaraningrat. (1998). Kebudayaan dan Mentalitas. Gramedia. Jakarta.

Kusumadewi, R. (2019). The Role of Marketing and Individual Environment Association in Elevating the Customer Value. Budapest International Research and Critics Institute-Journal (BIRCI-Journal), Vol 2, No 4, Page: 451-460.

Marlizar, et al. (2020). The Role of Market Orientation and Creativity in Affecting the Marketing Performance of Market Traders in Aceh Market Banda Aceh City. Budapest International Research and Critics Institute-Journal (BIRCI-Journal) Vol 3, No 2, Page: $1114-1127$ 
Mustopadidjaja. (2003). Reformasi Birokrasi sebagai Syarat Pemberantasan KKN, dalam Seminar Pembangunan Hukum Nasional VIII. Buku 3. Badan Pembinaan Hukum Nasional Departemen Kehakiman dan Hak Asasi Manusia Republik Indonesia. Perum Percetakan Negara Republik Indonesia.

Soetandyo Wignjosoebroto. (2002). Hukum: Paradigma, Metode dan Dinamika Masalahnya. Huma. Jakarta.

Sunarto. (2009). Televisi, Kekerasan dan Perempuan. Kompas Media Nusantara. Jakarta 